\title{
How internal heat loads of buildings affect the effectiveness of vertical greenery systems? An experimental study
}

\author{
Julià Coma ${ }^{1}$, Marta Chàfer ${ }^{2,3}$, Gabriel Pérez ${ }^{2, *}$, Luisa F. Cabeza² \\ ${ }^{1}$ Departament de Tecnologia de l’Arquitectura, Universitat Politècnica de Catalunya, Av. Dr. Marañón 44-50, \\ Barcelona, Spain. \\ ${ }^{2}$ GREiA Research Group, INSPIRES Research Centre, University of Lleida, Pere de Cabrera s/n, 25001 Lleida, \\ Spain. \\ ${ }^{3}$ CIRIAF - Interuniversity Research Centre, University of Perugia, Via G. Duranti 6706125 Perugia, Italy. \\ *Corresponding author: gperez@diei.udl.cat
}

\begin{abstract}
Nature-based solutions applied to the building skin, such as green roofs and vertical greenery systems, are standing out as the most promising by contributing with thermal improvements at building scale. From previous research done by GREiA research group at the University of Lleida (Spain), energy savings up to $58 \%$ were obtained by implementing vertical greenery systems on external building walls for cooling purposes. However, since there exist other passive and active energy saving technologies in the literature review that were limited their cooling and heating capacity after implementing internal heat loads, new experimental tests for two different vertical greenery systems simulating the heat loads in both, summer and winter were conducted in this research. Additionally, these experiments also improve the scarce and controversial literature for winter conditions. The results demonstrated that considering internal loads in experimental investigations is crucial for the results of the effectiveness of the green walls and green facades. The energy savings of VGS were reduced between $22.5 \%$ and 26.7 $\%$ because of the internal loads for cooling purposes, and increased about $3.6 \%$ and $3.1 \%$ for heating.
\end{abstract}

Key-words: Vertical greenery systems; passive energy savings; internal heat loads; buildings; occupancy.

\section{Introduction}

Buildings are responsible for more than $40 \%$ of global energy use and one third of global greenhouse gas emissions. The Energy Performance of Buildings Directive (EPBD) [1] and the Energy Efficiency 
Directive [2] enhance the regulation of energy performance in buildings. One of the main challenges is the reduction of the energy consumption for heating, ventilation and air conditioning (HVAC) systems. In addition, an increment for energy use up to $50 \%$ is expected by 2050 due not only to the growth of the global population but also because the improvements in economic development and living standards. Moreover, it is known that $20-60 \%$ of all energy used in buildings is affected by the building envelope design and construction [3]. Therefore, by improving the building skin design, large energy savings can be obtained due to the reduction of heating and cooling demands [4-6].

The envelope is one of the most important parts of a building, considering that it is the interface between the indoor and the outdoor conditions. It plays the major role in regulating interior temperatures and helps to determine the amount of energy required to maintain thermal comfort $[7,8]$. Therefore, minimizing the heat transfer through the building envelope is crucial to reduce the heating and cooling demands that are the largest energy end uses in both sectors, residential and commercial. Moreover, local climate influences the appropriateness and cost-effectiveness of final decisions pertaining to building envelope design and product selection [9]. In this context, among other passive technologies to improve the thermal performance of building envelopes those that are nature-based such as green roofs, and vertical greenery systems (VGS), are standing out as the most promising $[4,10]$. These innovative and environmental friendly envelope systems not only contribute in improving building skins, but they also provide multiple ecosystem services at city scale, for instance the reduction of $\mathrm{CO}_{2}$ emissions, the mitigation of the heat island effect, aesthetics enhancement, support to biodiversity in cities, etc. [5]. Perini et al. [6] stated in their study that VGS are effective natural sunscreens due to a reduction of the surface temperatures behind the green layer compared to the bare facades. In addition, Pérez et al. [4] demonstrated experimentally that VGS provide higher solar protection than artificial barriers in east, south and west facades in a continental Mediterranean climate.

Even though the passive cooling potential of VGS is widely demonstrated by numerical [11-13] and experimental studies for cooling periods [15-20], data about their performance during heating periods is still scarce and controversial [21-25]. Hence, the first objective of this study is to experimentally compare the thermal performance of two different vertical greening systems when implemented on east, south and west facades of small house-like cubicles for heating purposes. The selected VGS are a green wall made with evergreen species, and a double-skin green facade made by deciduous creeper plants.

The inclusion of vertical greenery systems on walls increases the energy storage capacity of the whole construction system [31], as a result, external thermal loads for example the direct solar radiation and the high outside temperatures during summer periods are supposed to be absorbed by building envelopes. Nevertheless, when referring to the indoor environment of buildings, occupancy is one of the most impacting energy consumption factors [23]. Specifically, internal heat loads generated by 
human activity (this includes sensible and latent heat of people, lighting, computers and household appliances) can be inadequate internal heat sources that increase the energy demand of the building and they are difficult to be transmitted outside of the building.

The literature review regarding VGS is generally focused on the benefits and effects of the vegetation at both the building and city level [24-26]. According to the reviewed papers, at the building level, the energy savings provided by these green systems are quantified by the reduction of the cooling/heating demand of a building. For their evaluation, researchers only have considered external environmental factors that affect the thermal performance of a building, such as climate, plant species, typology of the VGS, facade orientation, solar irradiation, air temperature, relative humidity, etc. However, indoor factors in particular occupant behaviour is one of the main reasons for systematic discrepancies between the expected energy demand and the final energy consumption in buildings [27]. The field of detailed exploration into occupant behaviour is relatively young [28], nevertheless, all the reviewed studies have confirmed that occupants significantly affect the energy requirements of a building through varying use patterns and energy-related behaviours. Thus, nowadays exists an important gap in the literature review about experimental studies that considers the influence of internal loads produced by occupancy on the final thermal performance of a vertical greenery system.

Concerning this topic, other studies have considered internal loads generated by occupancy to evaluate the thermal performance of different passive and active energy saving systems in buildings. Navarro et al. (2015) [29] experimentally studied the influence of internal heat loads in three different house-like cubicles. A reference system without any insulation material on the building envelope, one with insulation (projected polyurethane), and another one with phase change materials (PCMs) on the building envelope as passive systems for cooling purposes. In a similar experimental set-up, Romaní et al. (2018) evaluated the influence of the internal loads in a house-like cubicle with active radiant walls coupled to ground heat exchangers (GHE) [30]. Both studies highlighted the importance in considering internal loads because they could limit the cooling capacity of the systems, and they can even increase the energy consumption when compared to the reference construction system.

Since the thermal response of different passive and active energy saving systems implemented on building envelopes are highly affected by internal heat gains, the second objective of this paper is to evaluate their influence on the thermal performance of a green wall system, and a double-skin green facade for both, heating and cooling purposes. In this context, GREiA research group at the University of Lleida (Spain) is performing a long-term research in evaluating and characterizing the passive energy savings of VGS. The experimental results from previous studies demonstrated that VGS placed on building facades without internal heat gains can achieve up to 58\% energy savings for cooling, and minimize the extra energy consumption for heating in comparison to a reference building without 
vegetation [31]. In order to evaluate the effect of occupancy, and to extend the scarce literature available for heating purposes, new experiments considering scheduled internal heat loads with an office profile are presented in this paper.

\section{Materials and methodology}

\subsection{Experimental set-up}

This experimentation took place at the real-scale pilot plant located in Puigverd de Lleida in the northeast area of Spain under a continental Mediterranean climate that is classified as Cfa by the Köppen-Geiger system [32]. Three house-like cubicles were built to conduct this study with the same external dimensions of $3 \times 3 \times 3$ m and oriented N-S. They were constructed with an identical wall and roof construction systems and materials and without windows in order to avoid the heat loads due to the direct incidence of the solar radiation through the windows. These cubicles can be considered real scale experiments but under controlled conditions as in a laboratory set-up.

A green wall and a double-skin green facade were installed on the east, south and west facades of two of these identical cubicles in order to compare and measure the thermal behaviour and quantify the passive energy savings potential between green walls (evergreen) and green facades (deciduous) in summer and winter periods. Additionally, an identical cubicle without vegetation system was used as a reference system. These cubicles had the following characteristics:

- Reference cubicle: The walls have the following layers from inside to outside: gypsum as internal coating, alveolar brick (30 × $19 \times 29 \mathrm{~cm})$, and cement mortar as external protection coating. The overall thermal transmittance of the walls is $0.784 \mathrm{~W} \cdot \mathrm{m}^{-2} \cdot \mathrm{K}^{-1}$. The traditional flat roof has $1.5 \mathrm{~cm}$ plaster board, $8 \mathrm{~cm}$ of insulation (XPS), precast concrete beams with a ceramic floor arch $(25 \mathrm{~cm})$, concrete relieved pending formation of about $2 \%$, waterproof membrane, and finished with a single layer of rounded gravel of $7 \mathrm{~cm}$ (Figure 1a and Figure 2c. Constructive section: (a) Green wall, (b) Green Facade, and (c) Reference wall).

- Green wall cubicle: A green wall system was placed on the east, south and west facades. This green wall system consists of square modules ( $600 \times 400 \times 80 \mathrm{~mm}$ ) made of $3 \mathrm{~mm}$ recycled polyethylene that contains $8 \mathrm{~cm}$ of coconut fibre as substrate. Every square module has 24 small plants, which feed from 4 micro irrigation tubes (Figure 1b and 1c, and Figure 2a).

- Double-skin green facade cubicle: A double-skin green facade was installed as outermost layer on the east, south and west facades (Figures 1d and 1e, Figure 2b). 


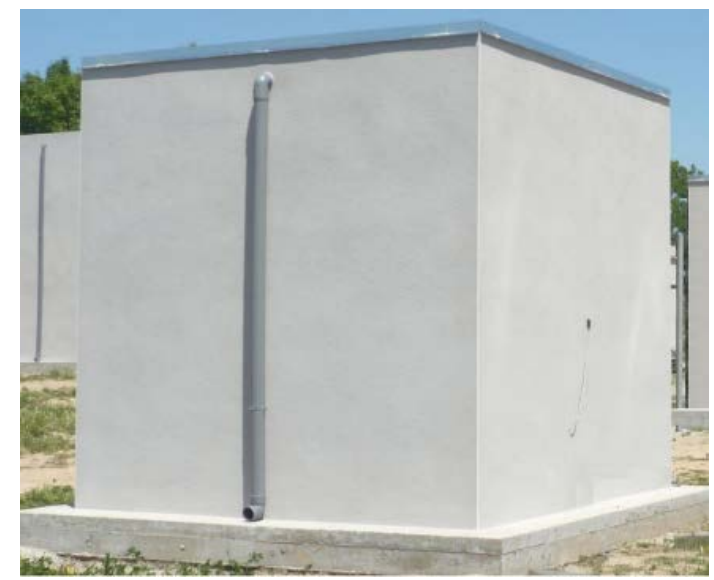

(a) Reference cubicle.

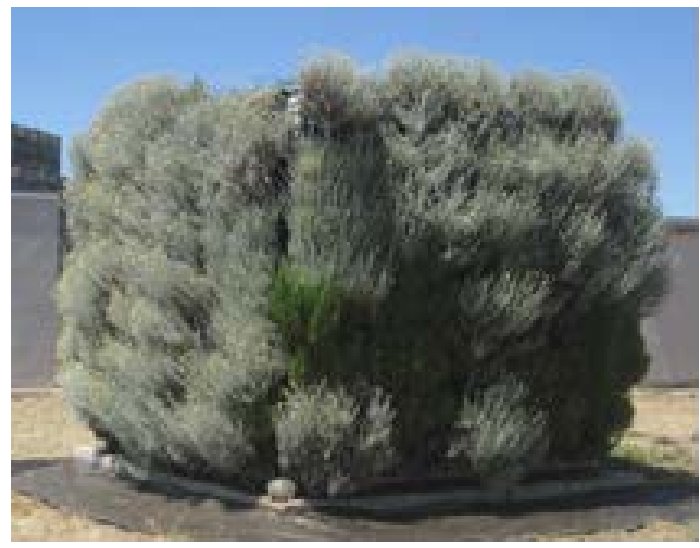

(b) Green wall in summer

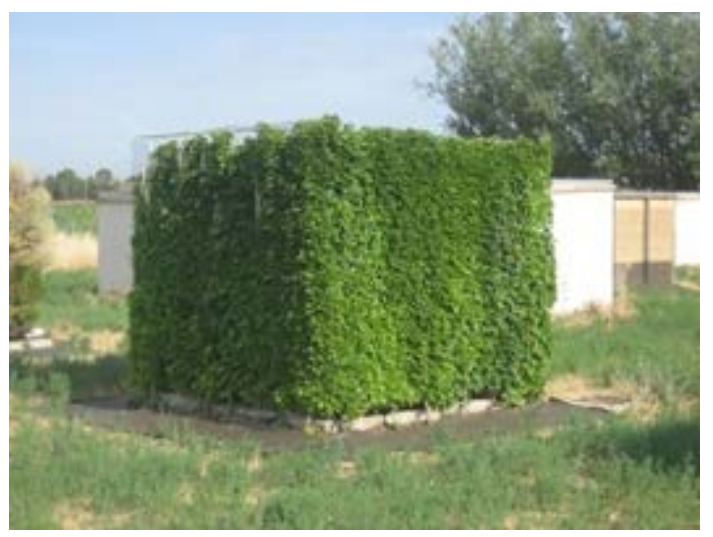

(d) Green facade in summer

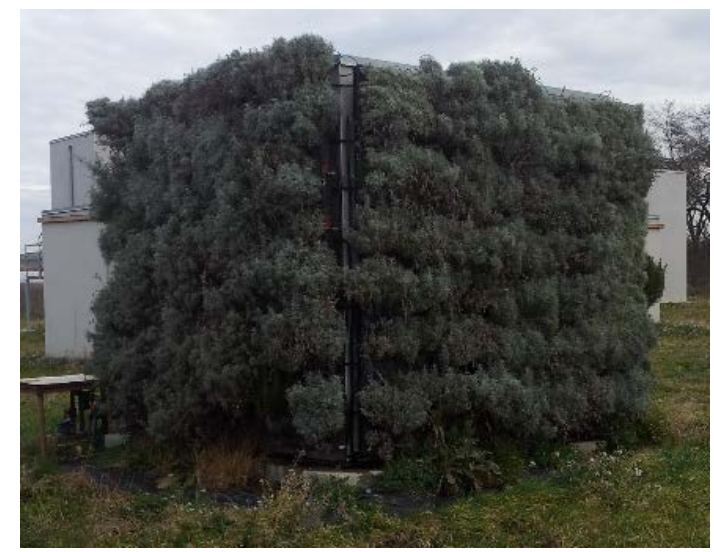

(c) Green wall in winter

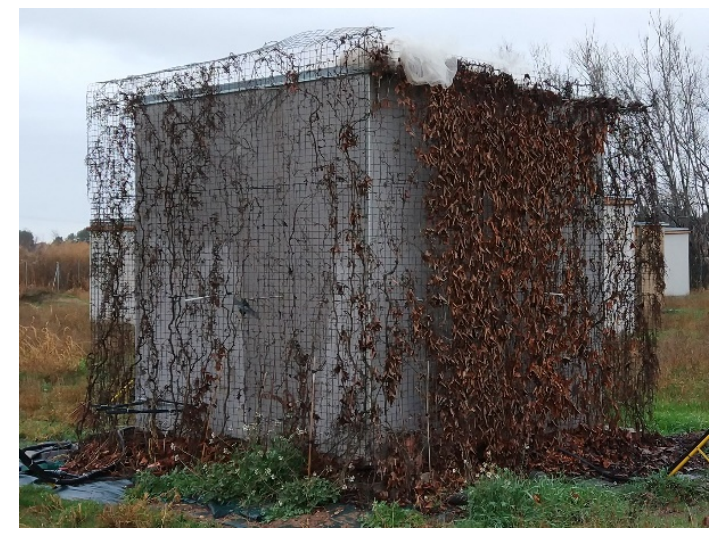

(e) Green facade in winter

Figure 1. Studied cubicles in the experimental set-up in Puigverd de Lleida. 
150
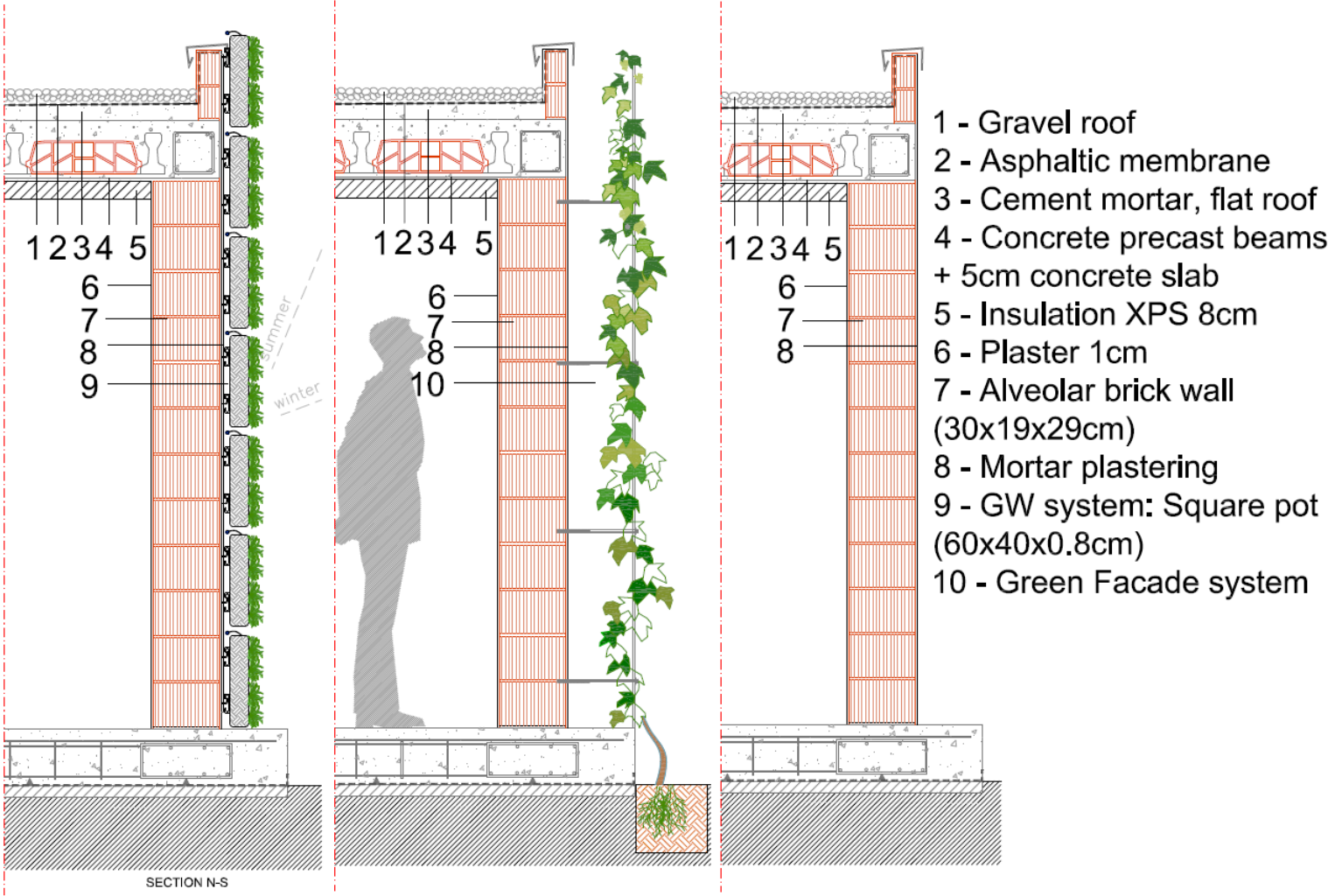

Figure 2. Constructive section: (a) Green wall, (b) Green facade, and (c) Reference wall

\subsection{Instrumentation}

A domestic heat pump was installed in each cubicle to cover the heating and cooling demands. To measure and analyse the thermal behaviour of these cubicles the following data was registered every 5 min interval (Figure 3 and table 1):

- Inner surface temperatures (walls, ceilings, and floors) $\left[{ }^{\circ} \mathrm{C}\right]$

- Outdoor surface temperatures of the walls (North, East, South, and West) [ $\left.{ }^{\circ} \mathrm{C}\right]$

- Outdoor air temperatures of the two VGS: air gap at $15 \mathrm{~cm}$ between wall and green facade, at $30 \mathrm{~cm}$ in the vegetation, and at $50 \mathrm{~cm}$ in front of the vegetation.

- Global horizontal solar irradiance $\left[\mathrm{W} \cdot \mathrm{m}^{-2}\right]$

- Electrical energy consumption of the HVAC system (Fujitsu Inverter ASHA07LCC) [kWh]

- Indoor and outdoor temperatures and relative humidity $\left[{ }^{\circ} \mathrm{C}\right],[\%]$ 


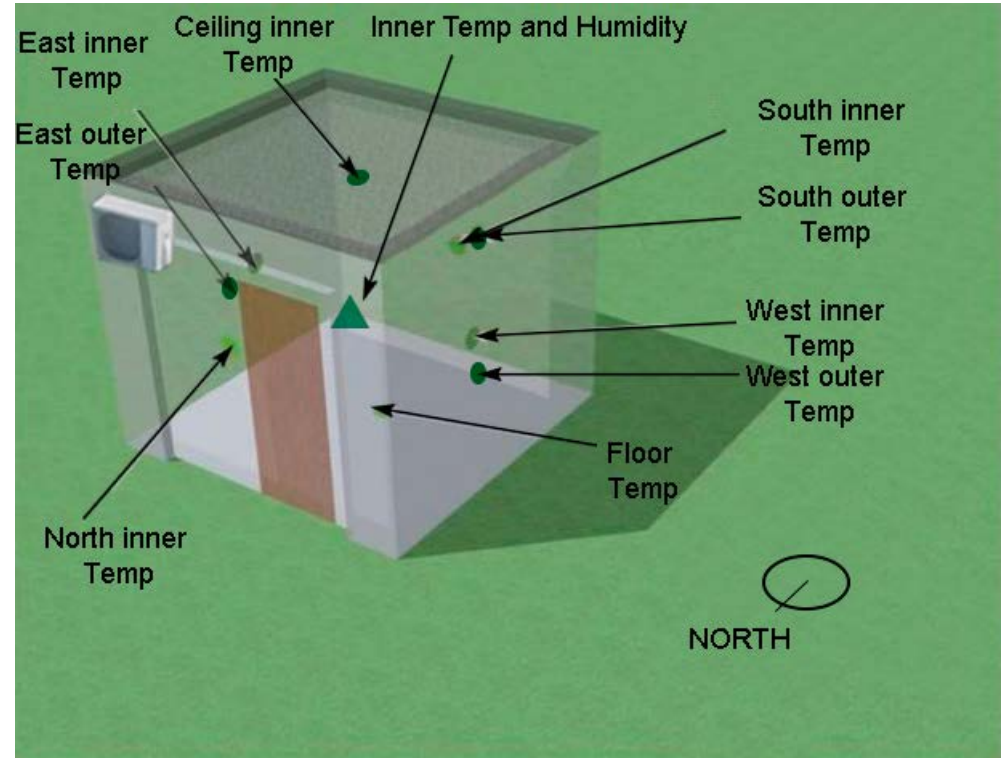

Table 1. Specific characteristics of the sensors used for monitoring the experimental set-up.

\begin{tabular}{|c|c|c|c|}
\hline Sensor Model/Type & Sensor application & Units & Features and accuracy \\
\hline Pt-100 DIN B sensor & $\begin{array}{l}\text { Surface temperature } \\
{\left[{ }^{\circ} \mathrm{C}\right]}\end{array}$ & 35 & $\begin{array}{l}\text { Temperature range }-40^{\circ} \mathrm{C} \text { to }+100^{\circ} \mathrm{C} \text {. } \\
\text { Accuracy Class B, maximum error of } \pm 0.3^{\circ} \mathrm{C}\end{array}$ \\
\hline $\begin{array}{l}\text { ELEKTRONIK } \\
\text { EE21- Pt-1000 A } \\
\text { sensor }\end{array}$ & $\begin{array}{l}\text { Indoor ambient } \\
\text { temperature/humidity } \\
{\left[{ }^{\circ} \mathrm{C}\right],[\%]}\end{array}$ & 4 & $\begin{array}{l}\text { Tolerance class A, DIN EN } 60751 \text {. Measuring range } 0 \text { to } \\
100 \%(\mathrm{RH}) \text {, and }-40 \text { to } 60{ }^{\circ} \mathrm{C} \text { (Temperature). Accuracy of } \pm \\
2 \% \text { ( } 0 \text { to } 90 \%) \text {, and } \pm 3 \% \mathrm{RH}(90 \ldots 100 \%) \pm 2 \% \text { (RH). }\end{array}$ \\
\hline $\begin{array}{l}\text { A Middleton Solar } \\
\text { pyranometer SK08 }\end{array}$ & Solar meter $\left[\mathrm{W} \cdot \mathrm{m}^{-2}\right]$ & 2 & $\begin{array}{l}\text { ISO } 9060 \text { Spectrally Flat Pyranometer of Class A for } \\
\text { measuring solar global radiation. Measuring range } 0 \text { to } 2000 \\
\text { W.m }{ }^{-2} \text {. Resolution } \pm 2 \mathrm{~W} \cdot \mathrm{m}^{-2} \text {. Spectral error }(0.28 \text { to } 4 \mu \mathrm{m})< \\
\pm 1 \mathrm{~W} \cdot \mathrm{m}-2 \text {. Spectral selectivity }(0.3 \text { to } 3 \mu \mathrm{m})< \pm 3 \% \text {. } \\
\text { Temperature response }< \pm 2 \%\left(-10 \text { to }+40^{\circ} \mathrm{C}\right) \text {. Tilt response } \\
\left(0-90^{\circ} \text {, at } 1000 \mathrm{~W} \cdot \mathrm{m}-2\right)< \pm 1 \% \text {. }\end{array}$ \\
\hline $\begin{array}{l}\text { Fujitsu Inverter } \\
\text { ASHA07LCC }\end{array}$ & Heat pump [kWh] & 3 & $\begin{array}{l}\text { Cooling capacity } 2.10 \text { kW; Heating capacity } 3.00 \text { kW. COP } \\
(4,8) \text { - Heating mode; EER }(5,4) \text { - Cooling mode. Thermal } \\
\text { performance completely evaluated in Payá et al. [33]. }\end{array}$ \\
\hline Circutor MK-30-LCD & $\begin{array}{l}\text { Energy consumption } \\
\text { of the heating/cooling } \\
\text { systems [kWh] }\end{array}$ & 3 & $\begin{array}{l}\text { Working temperature range } 0 \text { to }+50^{\circ} \mathrm{C} \text {. Current range } 300 \\
\text { mA to } 120 \text { A. Class } 1-10 \text { Wh ( } 100 \text { pulses } / \mathrm{kWh} \text { ). Max } 1 \\
\text { pulse/second. }\end{array}$ \\
\hline
\end{tabular}

\subsection{Internal loads methodology}

The internal loads existing in a real building were simulated using an infrared radiator HJM mod.301 (1000 W) adjustable at different power outputs. Moreover, a timer was used to establish the thermal scenario as in a Spanish office profile (9:00 a.m. - 02:00 p.m., and 04:00 - 07:00 p.m.). The considered 
case is an office with one person, a computer with screen and the lighting, obtaining a total power of about $330 \mathrm{~W}$ equivalent to $57.3 \mathrm{~W} \cdot \mathrm{m}^{-2}$. This case scenario was determined based on the ASHRAE standards (Ashrae handbook fundamentals, 1997) [34].

\subsection{Experiments}

The experimental set-up allows conducting two different types of experiments. Controlled temperatures with internal loads, and free floating tests also with internal loads were studied. In the experiments with controlled temperatures, heat pumps are used to maintain the indoor environment at a constant comfort temperature during the entire experiment. Then, the electrical energy consumption of the heating, ventilation and air conditioning system (HVAC) of all tested cubicles is compared using different temperature set points for summer and winter conditions. For heating periods an internal temperature about $22^{\circ} \mathrm{C}$ was considered because of the comfort conditions established in ASHRAE standard 55 that recommends from $20{ }^{\circ} \mathrm{C}$ to $25.5^{\circ} \mathrm{C}$, and from $23{ }^{\circ} \mathrm{C}$ to $26{ }^{\circ} \mathrm{C}$ for cooling [34]. Thus, an internal controlled temperature of $24{ }^{\circ} \mathrm{C}$ was established for summer.

Considering these variables, the following experiments were carried out in the experimental set-up in both, summer and winter (see table 2):

- Internal loads and controlled temperature: heat pumps were used to set the internal temperature of the cubicles at $24{ }^{\circ} \mathrm{C}$ in summer (cooling), and $22{ }^{\circ} \mathrm{C}$ in winter (heating), and infrared radiators HJM mod.301 were sued to simulate internal loads. Then, the energy consumptions of the heat pumps were compared.

- Internal loads and free floating conditions: no heating, ventilation and air conditioning system was used during these experiments. The evolution of indoor and outdoor temperatures of all cubicles were compared.

Table2. Performed tests in the experimental set-up.

\begin{tabular}{|c|c|c|c|}
\hline Type of experiment & Season & Set point & Duration (days) \\
\hline \multirow[t]{4}{*}{ With internal heat loads (A) } & \multirow[t]{2}{*}{ Summer (cooling) } & Free floating & 10 \\
\hline & & $24^{\circ} \mathrm{C}$ & 10 \\
\hline & \multirow[t]{2}{*}{ Winter (heating) } & Free floating & 10 \\
\hline & & $22^{\circ} \mathrm{C}$ & 13 \\
\hline Without internal heat loads (B) & Summer (cooling) & Free floating & - \\
\hline
\end{tabular}




\begin{tabular}{|l|l|l|l|}
\hline & & $24^{\circ} \mathrm{C}$ & 10 \\
\cline { 2 - 4 } & Winter (heating) & Free floating & - \\
\cline { 3 - 4 } & & $22^{\circ} \mathrm{C}$ & 13 \\
\hline
\end{tabular}

\section{Results and discussion}

\subsection{Internal loads and free floating conditions in summer}

212 Regarding the external wall surface temperatures of the evaluated systems, significant differences were 213 observed in all the orientations (east, south, and west). However, the maximum temperature variation was on the west facade since it is the orientation that received the highest thermal impact in summer. The temperature reduction by facade orientation and the consequent passive energy savings were particularly studied and confirmed by Pérez et al. (2017) [36], and Coma et al. (2017) [31] in the same location in a Mediterranean continental climate. Both studies concluded that VGS provide important temperature reductions in all the orientations in comparison to a bare wall. Pérez et al. (2017) stated that the shadow effect of green facade in the east and west orientations is quite significant and should be considered in an architectural design strategy with the same importance than south orientation. Additionally, the results obtained in their study concluded that west facade obtained the higher external temperature reductions up to $16.4{ }^{\circ} \mathrm{C}$.

On one hand, the west external wall surface temperature of the green wall ranged from $16.4{ }^{\circ} \mathrm{C}$ to 34.2 ${ }^{\circ} \mathrm{C}$ while the green facade showed a temperature variation from $15^{\circ} \mathrm{C}$ to $38.1^{\circ} \mathrm{C}$. On the other hand, the highest difference is on the reference wall, which ranged from $13.9{ }^{\circ} \mathrm{C}$ to $55.8^{\circ} \mathrm{C}$ (Figure 4). The internal temperatures of west walls were highly damped, especially in the two cubicles with vegetation that ranged from $26.8^{\circ} \mathrm{C}$ to $35.3^{\circ} \mathrm{C}$ for the green facade, and from $25.5^{\circ} \mathrm{C}$ to $33.5^{\circ} \mathrm{C}$ for the green wall for the summer representative period (Figure 3). Thus, important reductions up to $6.5^{\circ} \mathrm{C}$ and $4.7^{\circ} \mathrm{C}$ of the internal surface temperatures were observed for the green wall and the green facade cubicles, respectively, when compared to the reference one. Furthermore, these reductions were also detected in the indoor ambient conditions. The average of internal air temperature of green wall, green facade, and reference cubicles were $31{ }^{\circ} \mathrm{C}, 32.2{ }^{\circ} \mathrm{C}$, and $35.7^{\circ} \mathrm{C}$, respectively. These results showed a reduction of the indoor ambient temperatures up to $4.7^{\circ} \mathrm{C}$ that demonstrate the big potential of VGS in reducing the energy consumption of the cooling system even existing internal heat loads. 


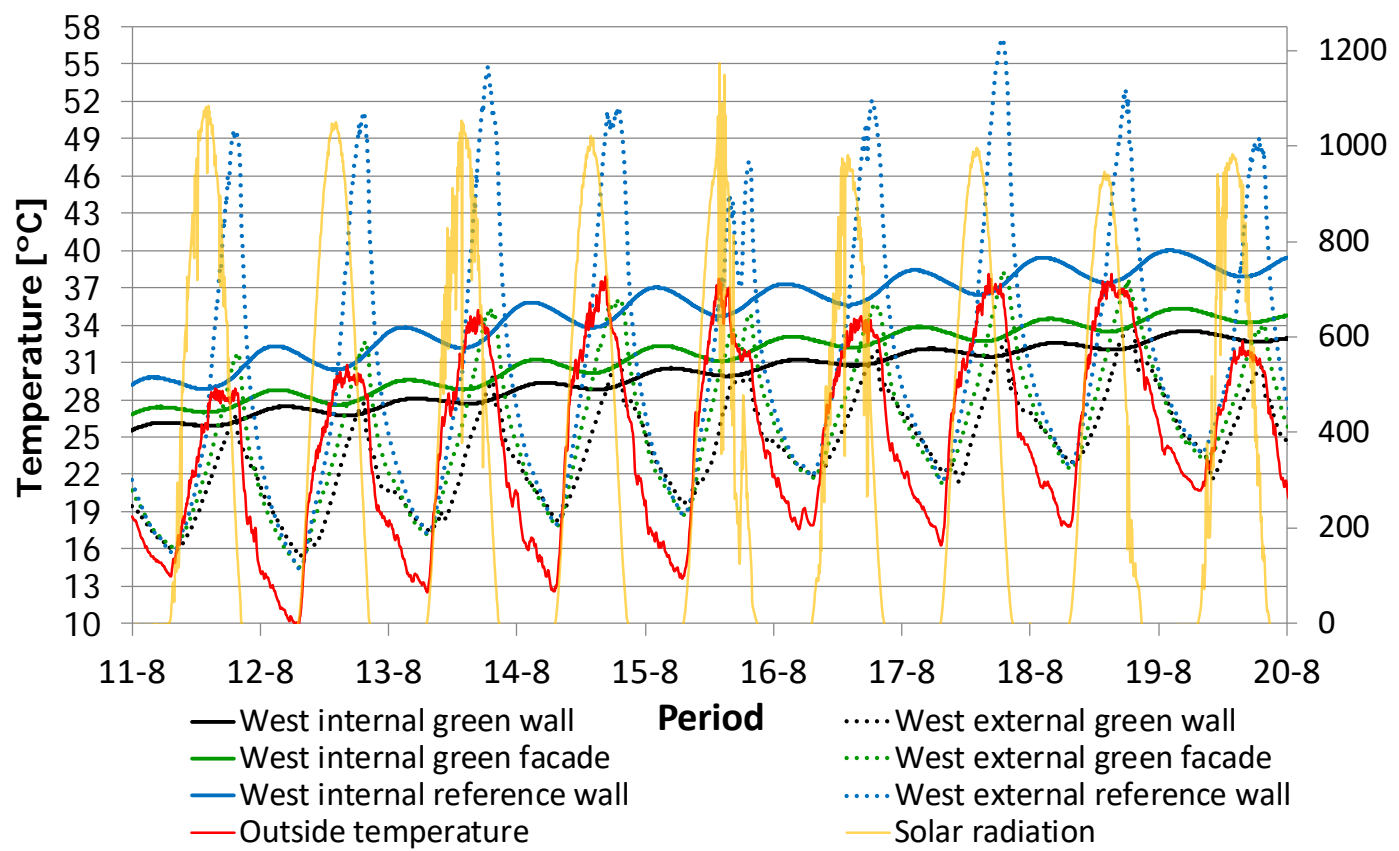

Figure 4. Indoor and outdoor surface wall temperatures of west orientation for ten consecutive summer days with internal loads and free floating conditions.

240 To perform a detailed analysis of daily thermal amplitudes of these systems in free floating conditions,

241 indoor air temperatures, and internal and external surface wall temperatures of two consecutive summer 242 days are presented in Figure 5. External surface temperatures of the reference wall and green facade 243 start increasing at 09.00 a.m., as expected, while in the green wall it is delayed $1.45 \mathrm{~h}$. This may be due 244 to the irrigation carried out in the green wall at 09:00 a.m. and at 07:00 p.m. Furthermore, the reference 245 wall made a quick increase from 02:00 p.m. until reach the peak of $57^{\circ} \mathrm{C}$ at 06:50 p.m. meanwhile the 246 peak temperatures reached for the green facade $\left(38.1^{\circ} \mathrm{C}\right)$ and green wall $\left(32.8^{\circ} \mathrm{C}\right)$ were lower and later because of the shade provided by the vegetation. 


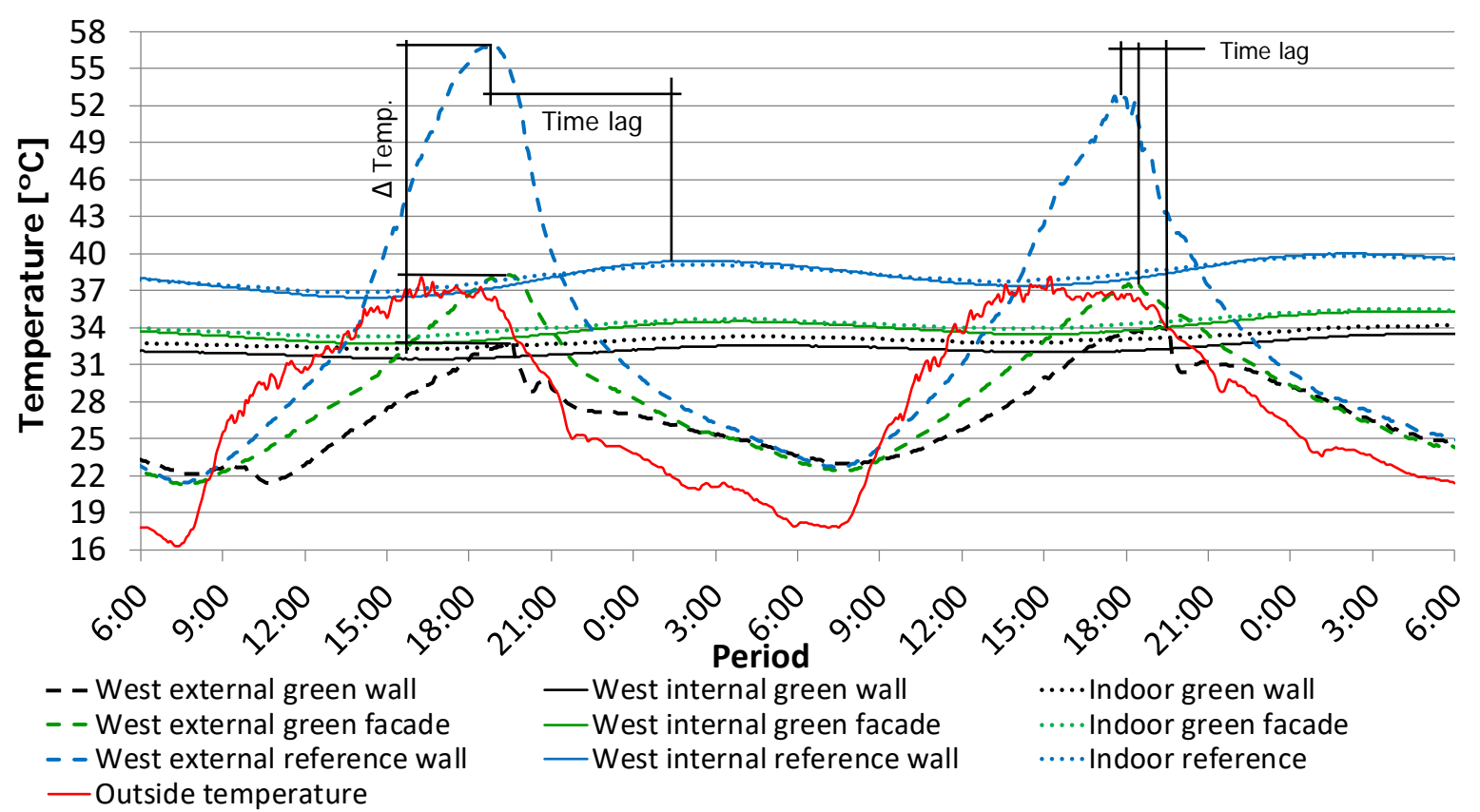

Figure 5. Indoor and surface temperatures of internal and external west walls for two consecutive summer days (August $11^{\text {th }}$ and $12^{\text {th }}, 2017$ ) with internal loads and free floating conditions.

The indoor air temperatures of all cubicles showed a similar temperature trend in comparison to the indoor wall temperatures. The mean indoor air temperature of the green wall, the green facade, and the reference cubicle showed slightly higher variations of $1{ }^{\circ} \mathrm{C}, 0,6{ }^{\circ} \mathrm{C}$ and $0,3{ }^{\circ} \mathrm{C}$, respectively, in comparison to the mean surface temperature of indoor walls.

Concerning both indoor air and inner surface temperature of the walls, the green wall cubicle showed the lowest daily variation between day and night, lower than $1{ }^{\circ} \mathrm{C}$, and the lowest indoor air temperature level for the representative summer period. The cubicle with a green facade registered a thermal amplitude of about $2.6^{\circ} \mathrm{C}$ and the reference cubicle showed the highest fluctuation with $3.5^{\circ} \mathrm{C}$. These results highlight the lowest sensitivity of the green wall cubicle to the external ambient conditions when compared to green facade and reference cubicles. This is probably due to the insulation effect provided by the addition of this constructive system (green wall) to the building facade.

Another important parameter that should be highlight is that peak temperatures of indoor surfaces were registered after midnight, 1:25 a.m., 2:00 a.m. and 3:30 a.m. for the reference, green facade, and green wall, respectively (Figure 5). So, the worst indoor ambient conditions were at night time because of the internal heat gains releases the energy indoors during the day time. These results revealed the potential capacity of these systems to implement different cooling strategies taking into consideration their peak load shifting capacity and the possible implementation of different technologies to reduce the final energy consumption.

Both vertical greenery systems reduced drastically the inner and outer surface wall temperatures in hot summer conditions in spite of the internal heat loads. However, even though the thermal performance 
272 of both VGS is much better compared to the reference system, the comfort conditions of indoor 273 environments are still far away to be achieved without cooling energy inputs, especially by the reference 274 system that registered a maximum indoor air temperature of $39.7^{\circ} \mathrm{C}$ on August $19^{\text {th }}$, 2017. The green 275 wall and green facade systems reached a maximum of $34.1^{\circ} \mathrm{C}$ and $35.5^{\circ} \mathrm{C}$, respectively in the same 276 day.

\subsection{Internal loads and controlled temperature at $24^{\circ} \mathrm{C}$ in summer}

Figure 6 shows the hourly energy consumed by each cubicle (green wall, green facade, and reference) and the solar irradiance of three consecutive summer days when internal temperatures were established at $24^{\circ} \mathrm{C}$ with and without internal heat loads, Figure A and Figure B, respectively. In terms of energy consumption important differences were appreciated. The reference system showed the highest energy consumption peak on August $22^{\text {nd }}$ at 17:00h with 251 Wh (Figure 6A), followed by the green facade with $216 \mathrm{Wh}$, and the green wall with $162 \mathrm{Wh}$ one hour after the reference peak (18:00 h). In addition, Figure 6A and Figure 6B show the delay between the electrical energy consumption peak and the solar irradiation peak (from 1 p.m. to 2 p.m.) that is about 5 hours for all cubicles. This is directly related because of the high thermal inertia of the alveolar bricks of the walls [33]. Figure 6B shows a reduction of up to $100 \mathrm{Wh}$ in the daily peak of energy consumption in comparison to Figure 6A with internal loads. Also, is important to highlight the different response of the vegetated cubicles in terms of hourly energy consumption. Both VGS showed similar peaks of consumption without internal loads (Figure 6B), however, when internal loads are implemented, green facade showed slightly higher energy consumption in comparison to the green wall system (Figure 6A). Along the representative period of 10 days, the green wall cubicle required 27.8\% less energy than the reference cubicle, followed by the green facade, with $16.7 \%$ less energy than the reference. 


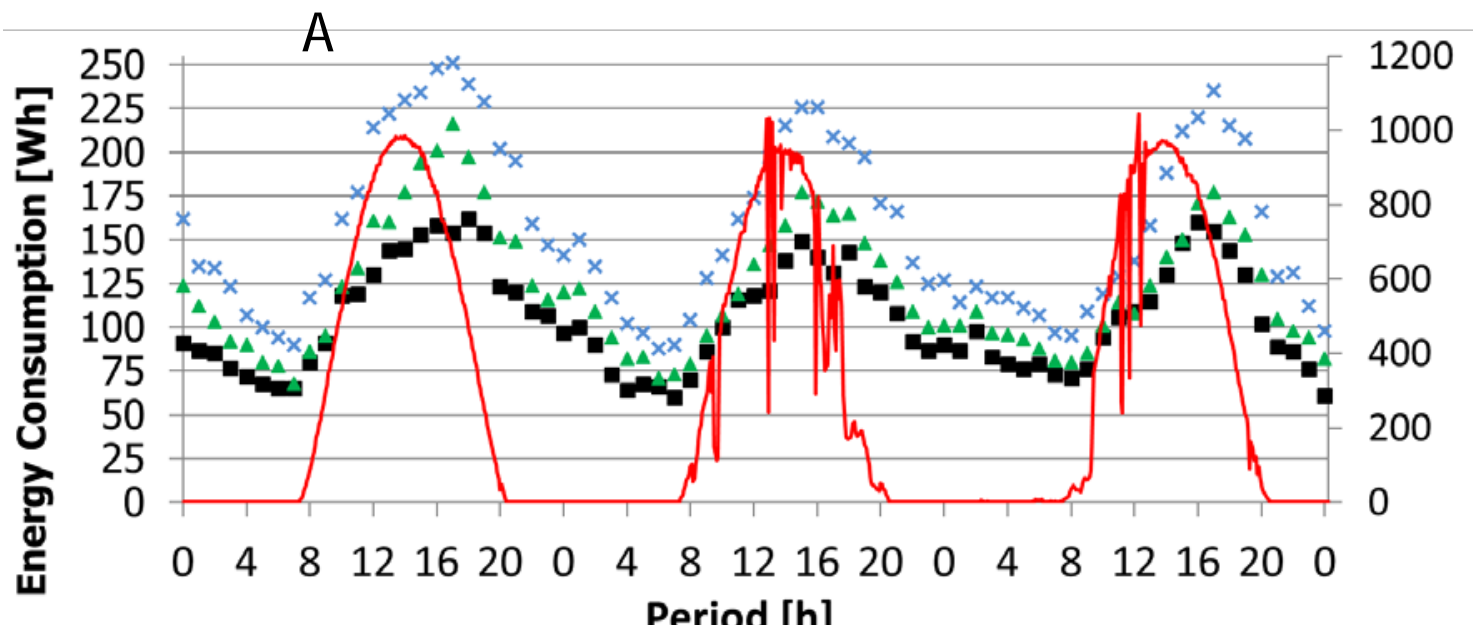

Period [h]
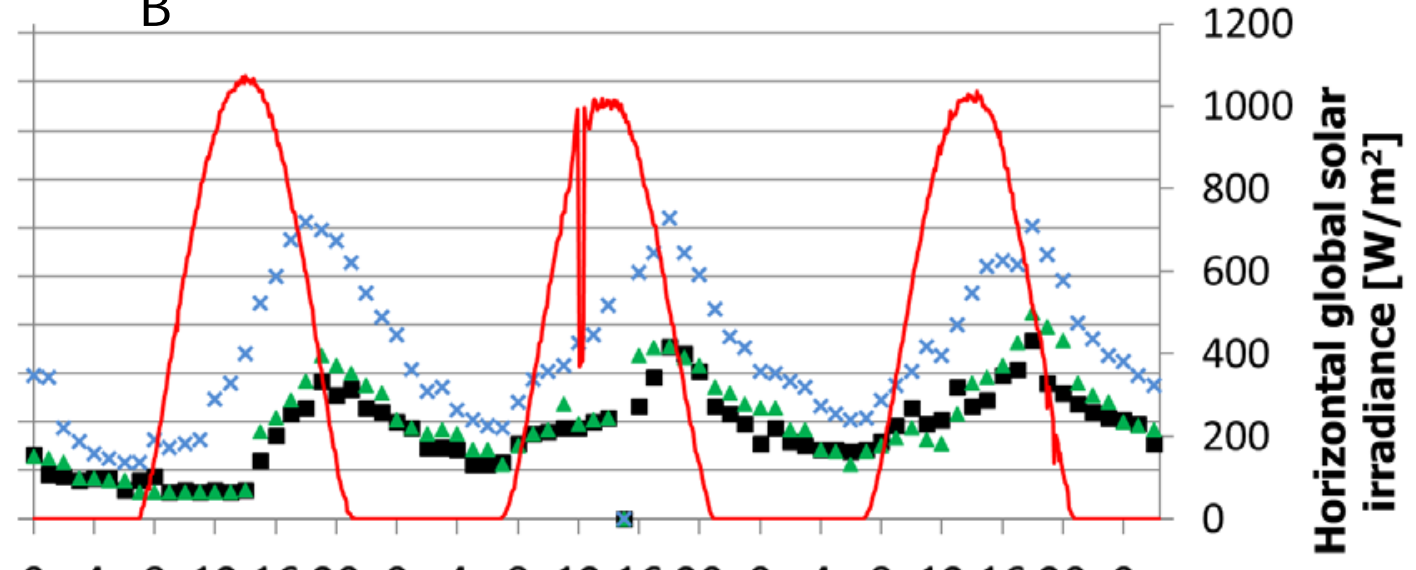

Figure 6. (A) Hourly energy consumption for August $22^{\text {nd }}, 23^{\text {rd }}$ and $24^{\text {th }}$ with internal loads and controlled temperature at $24^{\circ} \mathrm{C}$; (B) Hourly energy consumption for July $27^{\text {th }}, 28^{\text {th }}$ and $29^{\text {th }}$ without internal loads and controlled temperature at $24^{\circ} \mathrm{C}$.

Table 3 shows the minimum, maximum and average outside air temperatures, the average solar irradiance, and the cumulative electrical energy consumption of the heat pumps installed in all the analysed cubicles to ensure a proper comparison between the different representative summer periods. Also, the energy savings of both greenery systems for two different scenarios, with and without internal heat loads are presented.

Table 3. Total cumulative electrical energy consumption of the heat pumps for 10 consecutive days of uninterrupted cooling tests for the three studied cubicles with (A) and without (B) internal heat loads. 


\begin{tabular}{|c|c|c|c|c|c|c|c|c|c|}
\hline \multirow[t]{2}{*}{$\begin{array}{c}\text { Type of } \\
\text { experiment }\end{array}$} & \multirow[t]{2}{*}{ Month } & \multirow[t]{2}{*}{$\begin{array}{l}\text { Period } \\
\text { [days] }\end{array}$} & \multirow{2}{*}{$\begin{array}{l}\text { Min./ Max./ Avg. } \\
\text { outside air } \\
\text { temperature }\left[{ }^{\circ} \mathrm{C}\right]\end{array}$} & \multirow{2}{*}{$\begin{array}{c}\text { Average solar } \\
\text { irradiance } \\
{\left[\mathbf{W} \cdot \mathbf{m}^{-2}\right]}\end{array}$} & \multicolumn{3}{|c|}{$\begin{array}{l}\text { Accumulated electrical } \\
\text { energy consumption of } \\
\text { the HVAC [kWh] }\end{array}$} & \multicolumn{2}{|c|}{$\begin{array}{c}\text { Average } \\
\text { energy savings } \\
{[\%]}\end{array}$} \\
\hline & & & & & $\mathrm{GW}^{*}$ & $\mathrm{GF}^{*}$ & $\mathrm{RF}^{*}$ & $\mathrm{GW}^{*}$ & $\mathrm{GF}^{*}$ \\
\hline $\begin{array}{l}\text { With internal heat } \\
\text { loads } 2017 \text { (A) }\end{array}$ & August & 10 & $14.8 / 39.6 / 25.4$ & 495.1 & 22.56 & 26.04 & 31.24 & 27.8 & 16.7 \\
\hline $\begin{array}{l}\text { Without internal } \\
\text { heat loads } 2017 \text { (B) }\end{array}$ & July & 10 & $14.3 / 39.8 / 25.6$ & 575.1 & 9.19 & 10.44 & 18.47 & 50.3 & 43.4 \\
\hline
\end{tabular}

${ }^{*} \mathrm{GW}$ : green wall; GF: green facade; RF: reference.

314 On one hand, the difference of the energy savings between case A and case B after 10 days under similar 315 summer conditions demonstrates that both cubicles with VGS are highly affected by the simulated 316 occupancy in cooling periods. Green wall and green facade cubicles reduced their energy saving 317 capacity from $50.3 \%$ to $27.8 \%$, and from $43.4 \%$ to $16.7 \%$, respectively, because the heat loads cannot 318 be easily dissipated to outdoors, increasing the energy consumption under the same climatic conditions.

319 Similar effects were observed by Navarro et al. [29] in their study when three buildings with PCM were 320 compared considering internal heat loads, and by Romaní et al. [30] when the thermal performance of 321 radiant walls including tests with internal heat loads were experimentally evaluated. Nevertheless, the 322 results of both VGS still show a high potential capacity in reducing the energy demand of a building in a continental Mediterranean climate.

324 When comparing the results of this paper with those obtained by Coma et al. 2017 in [31], where internal 325 heat loads were not considered, slight differences in terms of energy savings were detected in summer.

326 The green wall showed a reduction from $58 \%$ to $50.3 \%$ in terms of energy savings for a similar period 327 of 10 days. It is attributed because of the relation between the efficiency of these systems and the solar 328 irradiation $\left[\mathrm{Wh} / \mathrm{m}^{2}\right]$, where the lower the solar irradiation the lower the energy savings of VGS [31]. 329 However, in the same period the green facade system increased, as expected, from $33.3 \%$ to $43.4 \%$ its 330 efficiency. This phenomenon could be attributed to the Leaf Area Index (LAI) of the Boston Ivy plant, 331 which has been thickening every year since the vegetation was planted in 2014. This phenomenon is well studied by Pérez et al. 2017 [36] who demonstrated the relation between the LAI number of a green facade and the energy savings provided. In addition to the LAI index, the representative summer period of 2016 was warmer than in 2017 with higher mean temperature of $2.8{ }^{\circ} \mathrm{C}$, and higher mean solar irradiance of $20.8 \mathrm{~W} \cdot \mathrm{m}^{-2}$.

336 Finally, the performed cooling experiments have highlighted the importance in considering internal heat 337 loads, since the heat source is located inside, and passive energy saving systems such as green infrastructures, Trombe walls, cool roofs, sunscreens, and high insulation thicknesses, are generally implemented on the outer skin of a building. Thus, passive systems can reduce the heat gains/losses throughout the building envelope but are not able to remove internal heat loads generated by human behaviour for cooling purposes. 


\subsection{Internal loads and free floating conditions in winter}

345

346

347

348

349

350

351

352

353

354

355

356

357

358

359

This experiment was performed at the end of December 2017, when the outside daily temperatures ranged between $-2^{\circ} \mathrm{C}$ and $19.4^{\circ} \mathrm{C}$. In this case, only internal heat loads according to an office profile scenario from 09:00 a.m. to 02:00 p.m. and from 04:00 to 07:00 p.m. was used. Since the south facade receives the highest solar irradiance in winter for Mediterranean climates, this orientation was selected as the most representative. Figure 7 shows the evolution of the internal and external south wall temperature for the studied cubicles, and the outdoor air temperature and solar radiation. Concerning the external surface temperatures during the representative foggy period (from December $23^{\text {rd }}$ to $26^{\text {th }}$, 2017) the cubicle with a green wall showed the lowest thermal oscillation between day and night ranging from $-0.2{ }^{\circ} \mathrm{C}$ to $3.2^{\circ} \mathrm{C}$, followed by the green facade cubicle that ranged from $-1{ }^{\circ} \mathrm{C}$ to $4.4{ }^{\circ} \mathrm{C}$, and finally the reference wall ranged from $-1.9^{\circ} \mathrm{C}$ to $6^{\circ} \mathrm{C}$. In terms of internal surface wall temperatures, the green wall cubicle showed lower daily temperatures of about $1^{\circ} \mathrm{C}$ when compared to the reference and green facade cubicles. The average of indoor air temperature was $7.7^{\circ} \mathrm{C}, 8.2^{\circ} \mathrm{C}$ and $8.9^{\circ} \mathrm{C}$ for green wall, green facade and reference cubicle, respectively during the foggy days.

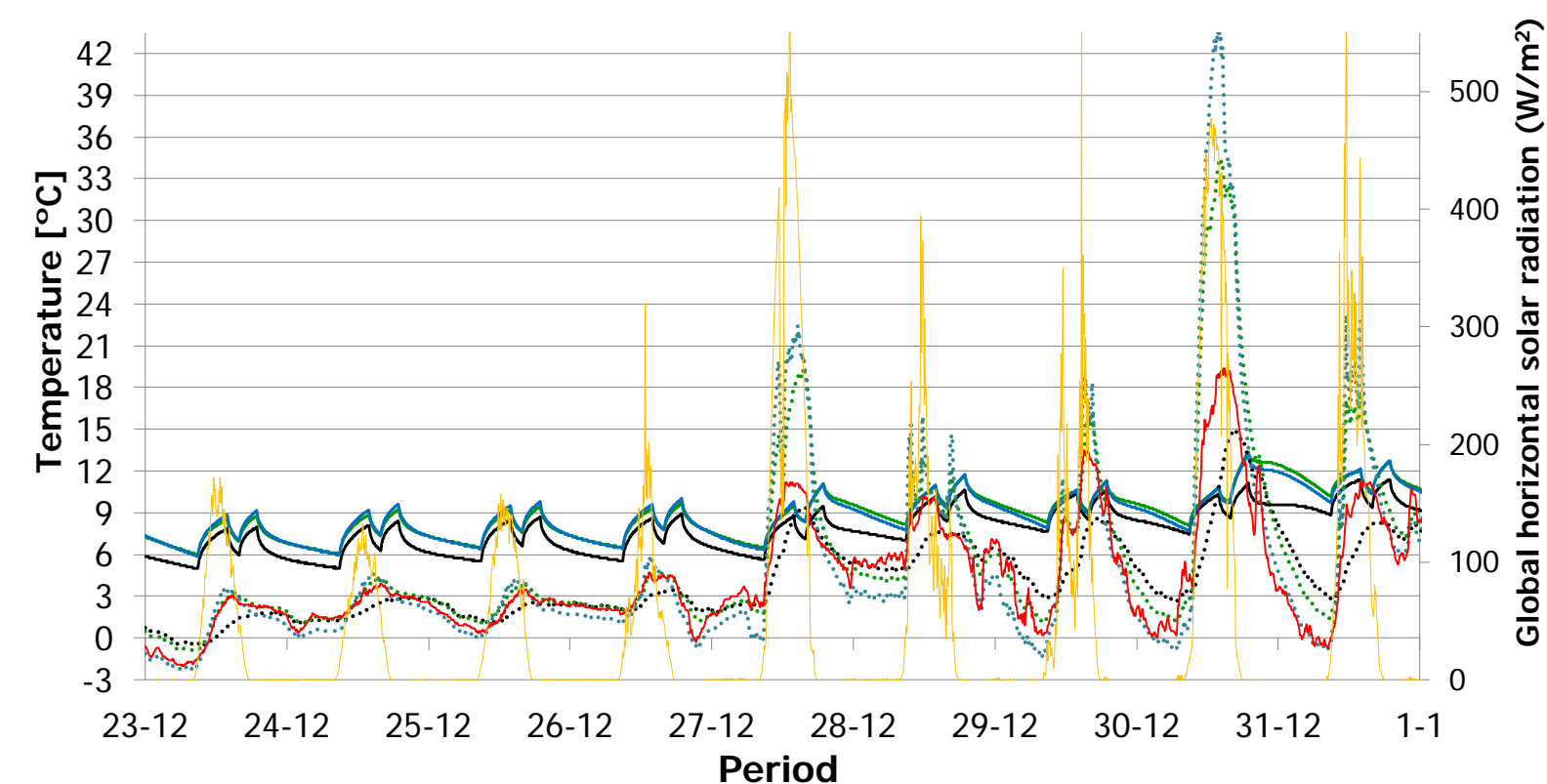

- South internal Green wall -.... South external Green wall - Outside temperature

- South internal Green facade — -South internal Reference wall .... South external Green facade …. South external Reference wall Solar radiation 
364 During a sunny period in winter (from December $27^{\text {th }}$, 2017 to January $1^{\text {st }}, 2018$ ) the green wall cubicle 365 showed the same internal temperature trend during daytime in comparison to the reference and green 366 facade cubicles. Nevertheless, during night-time internal temperatures of green facade and reference 367 cubicles decreased rapidly until reach the same temperatures than green wall cubicle (Figure 7). The 368 average of indoor air temperature in winter sunny days was slightly higher in all cubicles, $9.7^{\circ} \mathrm{C}, 10.3$ $369{ }^{\circ} \mathrm{C}$ and $10.7^{\circ} \mathrm{C}$ for green wall, green facade and reference cubicle, respectively. Regarding the external 370 surface temperatures, it is expected that green wall does not allow direct solar gains, however, higher 371 external surface temperatures up to $5^{\circ} \mathrm{C}$ were observed at night because of the night radiative protection 372 of the modules (Figure 7).

373 In order to evaluate more accurately the results obtained here, two representative winter sunny days 374 (December $29^{\text {th }}$ and $30^{\text {th }}$, 2017) were analysed and are presented in Figure 8. The thermal behaviour of 375 internal ambient temperatures after implementing daily internal heat loads has a slightly different 376 decreasing trend in each studied cubicle, especially at night from 07:00 p.m. to 09:00 a.m (December $37730^{\text {th }}$, 2017). The reference reduced the indoor air temperature form $14.1{ }^{\circ} \mathrm{C}$ to $10.1{ }^{\circ} \mathrm{C}\left(4^{\circ} \mathrm{C}\right)$, the green 378 facade from $13.5^{\circ} \mathrm{C}$ to $9.7^{\circ} \mathrm{C}\left(3.8^{\circ} \mathrm{C}\right)$, and green wall from $12.6^{\circ} \mathrm{C}$ to $9.2^{\circ} \mathrm{C}(3.4)$.

Regarding external surface wall temperatures, the cubicle with a green facade presented a slightly similar temperature trend than the reference cubicle, but with lower peaks of maximum and minimum 382 temperature because of the deciduous vegetation and the permanent branches, as expected. In addition, 383 is important to mention that green facade and reference systems do not registered important delays in 384 the external peak temperatures in comparison to the outside ambient temperatures, nevertheless, external green wall showed a 100 min delay between these peaks.

387 Concerning internal wall temperatures, both green facade and reference showed a similar trend during the office profile increasing from $7.7^{\circ} \mathrm{C}$ to $13.4^{\circ} \mathrm{C}$ (09:00 a.m. to 07:00 p.m., December $30^{\text {th }}$, 2017), while green wall showed a lower increment of $3.8^{\circ} \mathrm{C}$ (from $7.4^{\circ} \mathrm{C}$ to $11.2^{\circ} \mathrm{C}$ ) in the same period.

390 After the office profile, from 07:00 p.m. to 09:00 a.m., green wall decreased from $11^{\circ} \mathrm{C}$ to $8.8^{\circ} \mathrm{C}(2.2$

$391{ }^{\circ} \mathrm{C}$ ), while green facade and reference cubicles showed higher reductions, from $13.4{ }^{\circ} \mathrm{C}$ to $10{ }^{\circ} \mathrm{C}(3.4$

$392{ }^{\circ} \mathrm{C}$ ). Once again, the higher thermal inertia of the green wall is reflected in the indoor environment under 393 free floating conditions. 


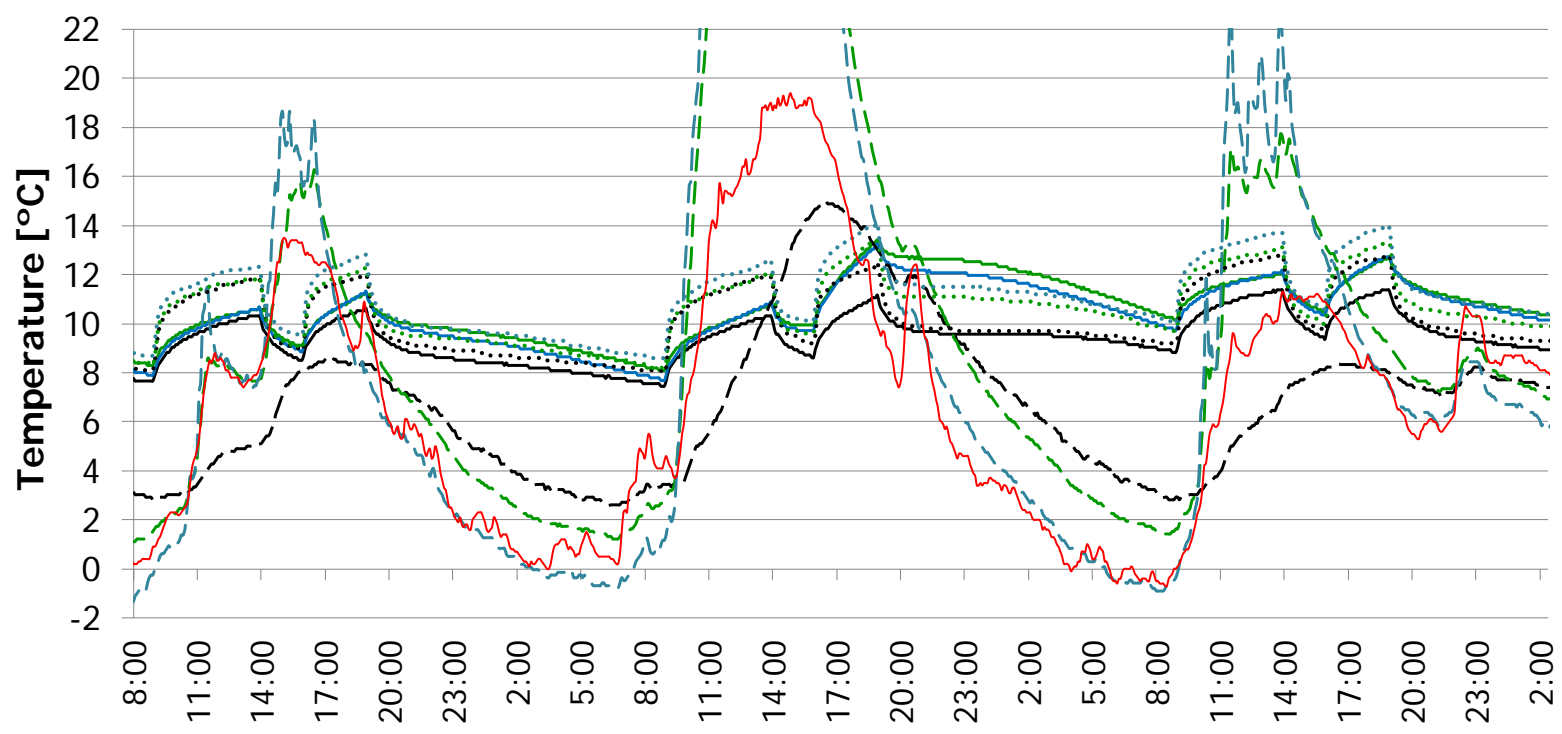

\section{Period}

\section{- South internal Green wall - -South external Green wall .....Indoor green wall}

- South internal Green facade - -South external Green facade

..... Indoor green facade
- South internal Reference wall

- - South external Reference wall

...... Indoor reference

Figure 8. Internal and external south wall temperatures, and indoor air temperatures for two representative sunny days with free floating conditions plus heating loads in winter

Higher values of solar irradiation and outdoor ambient temperatures had a direct influence on the external, but also in the internal surface wall temperatures for both green facade and reference cubicle. The increase of the solar irradiance and outside air temperatures from December $30^{\text {th }}$ to $31^{\text {st }}, 2017$ increased up to $2{ }^{\circ} \mathrm{C}$ the internal surface temperatures of these cubicles, as well as the indoor air temperatures (Figure 8), while these benefits were limited by green wall that was only increased the surface wall temperature and the indoor temperature by $0.7^{\circ} \mathrm{C}$ and $0.9^{\circ} \mathrm{C}$, respectively.

In both, foggy and sunny periods, the green wall showed the lowest internal and external temperature variation followed by the green facade, and finally the reference cubicle. These results showed the highest sensitivity of green facade and reference cubicles to the climate conditions in comparison to the green wall cubicle, and highlights the findings regarding the thermal stability coefficient calculated by Coma et al. 2017 in [31]. These results are also in agreement with those published by Tudiwe and Korjenic, 2017 [21] in warm and temperate climate conditions (Cfb) where the fluctuation rate of the surface temperatures was reduced with a green wall. Even though the reference and green facade cubicles registered lower external wall temperatures at night in comparison to the green wall cubicle, the mean indoor temperature in winter sunny days is lower in the green wall cubicle. This fact is because of the big difference between peak temperatures of the wall reached by green facade $\left(34.5{ }^{\circ} \mathrm{C}\right)$ and reference $\left(44.2{ }^{\circ} \mathrm{C}\right)$ compared to the green wall $\left(15^{\circ} \mathrm{C}\right)$ during the day. However, in foggy days, this trend changes, and green wall registered higher mean temperatures of external wall about $0.2{ }^{\circ} \mathrm{C}$ 
compared to a bare wall cubicle. Similar results were obtained by Tudiwe and Korjenic 2017 [21] where

418 the average surface temperature of the green wall system were all day lower than bare wall temperatures

419 in warm days and high solar radiation. Those authors also concluded that the thermal resistance of a

420 VGS depends on its construction and the ventilation gap and the results cannot be generalised to all greening systems.

422

The experimental results presented here showed that in sunny winter periods external temperatures of the bare wall are higher compared to a green wall in day time, but during night time bare wall shows lower external surface temperatures. In terms of daily mean temperatures, the green wall showed the lowest values in sunny days with high solar radiation in comparison to the reference and green facade cubicles, but green wall showed an interesting potential to maintain warmer the external surface temperatures with periods without solar gains (foggy and cloudy days).

\subsection{Internal loads and controlled temperatures at $22^{\circ} \mathrm{C}$ in winter}

The maximum differences in terms of indoor and outdoor wall temperatures among all the three evaluated cubicles were observed on the south facade. On one hand, the external surface wall temperature of the reference cubicle showed the highest variation from $-6.8^{\circ} \mathrm{C}$ to $39.7^{\circ} \mathrm{C}$, but the warmer mean temperature with $8{ }^{\circ} \mathrm{C}$, as expected. The temperatures of green facade ranged from $-3{ }^{\circ} \mathrm{C}$ to $27.4^{\circ} \mathrm{C}$, with a similar mean temperature of $7.9^{\circ} \mathrm{C}$. On the other hand, green wall cubicle registered a damped temperature range from $-1.7^{\circ} \mathrm{C}$ to $13.2^{\circ} \mathrm{C}$ with the lower mean temperature with $5.2^{\circ} \mathrm{C}$.

Figure 9 shows the hourly electrical energy consumed of the heat pumps when internal temperatures of the three studied cubicles were set at $22{ }^{\circ} \mathrm{C}$ with and without internal heat loads, Figure 9A and Figure 9B, respectively. The reference system showed the lower energy consumption for heating purposes in case A (with internal heat loads) and in case B (Without internal heat loads), as expected. The results of indoor air temperatures presented in Figure 8, where the mean indoor temperature of reference cubicle was the highest in comparison to both VGS, confirm the lower energy consumed by the reference cubicle (Figure 9A) to achieve the indoor desired temperatures.

447 Figure 9A also clearly identifies the contribution of internal heat loads between 9 a.m. and 2 p.m., and from 4 p.m. to 7 p.m. because the lowest consumption peaks in all cubicles match with the office profile time (case A). Thus, their energy consumption increase from 7 p.m., until the sunrise at 8 a.m. Regarding the hourly energy consumption, on one hand, case B (without internal loads) showed less daily variation between minimum and maximum peaks of consumption ranging from $180 \mathrm{Wh}$ to 288 Wh. On the other hand, case A (with internal heat loads) showed higher range between minimum and 
maximum peaks of energy consumption (from $175 \mathrm{Wh}$ to $330 \mathrm{Wh}$ ). Also, it is important to highlight

454 that during cloudy or foggy days the difference in terms of hourly energy consumption between all the 455 cubicles was lower than $25 \mathrm{Wh}$.
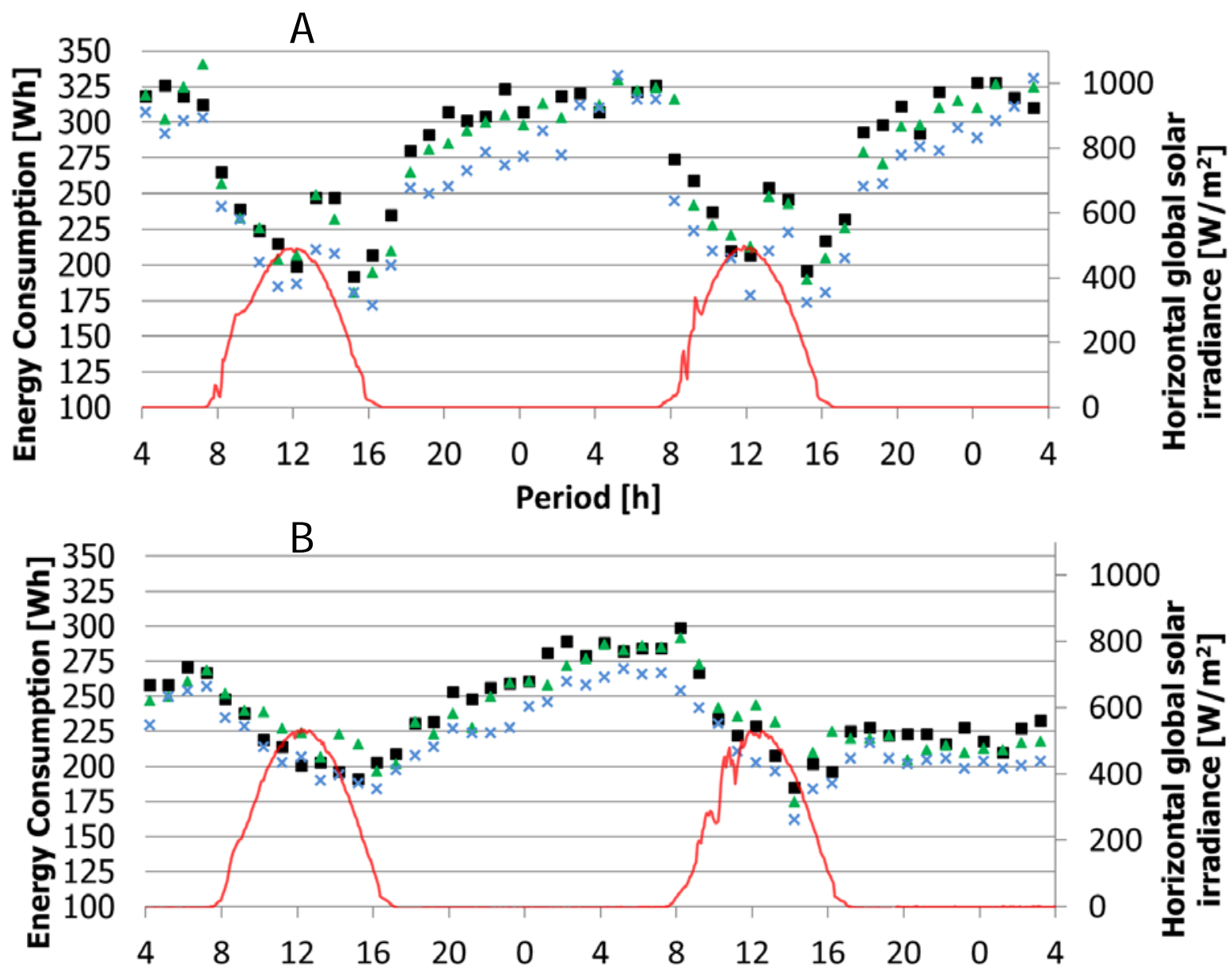

- Green Wall $\Delta$ Green Facade ${ }^{\circ}$ Reference -Solar Radiation

457

\section{Period [h]}

461

Both green systems showed a similar trend in terms of energy consumption during 26 representative 463 days of winter even implementing two different vertical greenery systems on the walls, one evergreen and one deciduous but with dry branches and some remaining leaves (Figure 1e). Within the first

Figure 9. (A) Hourly energy consumption for December $4^{\text {th }}$ and $5^{\text {th }}$ with internal loads and controlled temperature at $22^{\circ} \mathrm{C}$; (B) Hourly energy consumption for January $18^{\text {th }}$ and $19^{\text {th }}$ without internal loads and controlled temperature at $22{ }^{\circ} \mathrm{C}$. representative period of winter (13 days), the cubicle with a green wall showed the highest accumulated

467 Slightly lower accumulated energy consumption was observed by the reference cubicle that consumed $468 \quad 77.87 \mathrm{kWh}$. 
Figure 10 shows internal and external wall temperatures and how the solar irradiance and the outside temperature influence the daily energy consumption. On one hand, the lowest values in terms of energy consumption for the representative days in winter were detected on December $11^{\text {th }}$, 2017 coinciding with the lowest levels of solar irradiance and the highest outside air temperatures during the day but especially at night (Figure 10). In addition, the higher night temperature peaks observed on December $10^{\text {th }}, 11^{\text {th }}$, and $12^{\text {th }}$, 2017 resulted in the lowest energy consumption period of the heat pumps for all the studied cubicles, as well as the lower the difference in the energy consumed between all of them. Hence, the lower the difference between daily average outdoor temperatures and indoor comfort condition (22 $\left.{ }^{\circ} \mathrm{C}\right)$, the lower the energy consumption observed.

478

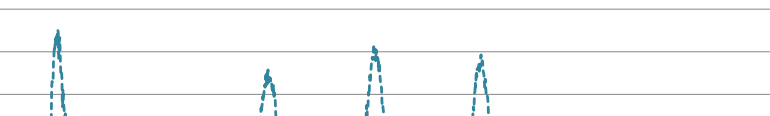

28

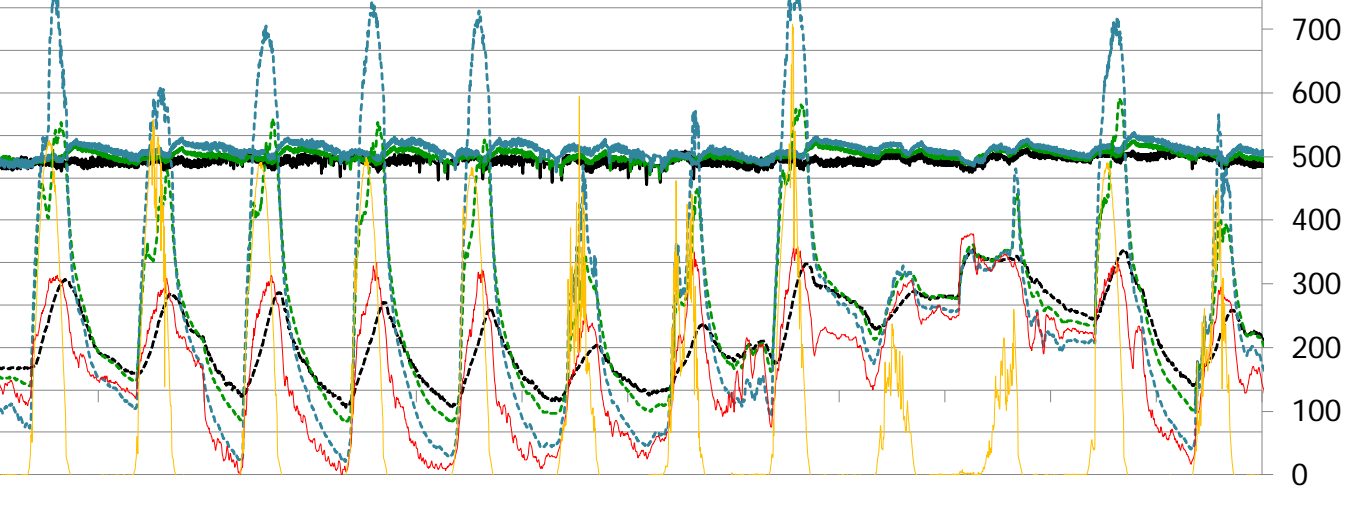

0

2-12 $\quad 3-12 \quad 4-12 \quad 5-12 \quad 6-12 \quad 7-12 \quad 8-12 \quad 9-12 \quad 10-12 \quad 11-12 \quad 12-12 \quad 13-12 \quad 14-12$ Period

- South internal green wall ----South external green wall - Outside temperature
- South internal green facade - South internal reference

----South external green facade ----South external reference Solar radiation

Figure 10. Indoor/outdoor surface wall temperatures and outside temperature and solar radiation.

481

482

483

484

485

486

487

488

489

490

491

492

493

On the other hand, the highest daily energy consumption was recorded on December 7th, 2017, where the outdoor ambient temperature oscillation ranged from $7{ }^{\circ} \mathrm{C}$ (daytime) to $-7.4{ }^{\circ} \mathrm{C}$ at night and the solar irradiation was reduced due to the fog. This fact can be caused because of the night temperatures registered on previous nights of December $4^{\text {th }}, 5^{\text {th }}$, and $6^{\text {th }} 2017$ that reached peaks of low temperatures of $-8.2^{\circ} \mathrm{C},-8.0^{\circ} \mathrm{C}$, and $-7.6^{\circ} \mathrm{C}$, respectively.

Regarding indoor surface temperatures of the walls, all the studied cubicles showed a similar trend following the internal set temperature at $22{ }^{\circ} \mathrm{C}$, as expected (Figure 9). However, the indoor wall temperatures of green facade and reference systems were sensitive to the daily solar gains stored in the south wall, rising their temperatures $1{ }^{\circ} \mathrm{C}$ and $2{ }^{\circ} \mathrm{C}$ above the set point, respectively, with an approximate time lag of $5 \mathrm{~h}$ between temperature peaks. 
Table 4 summarizes the main results in terms of energy consumption obtained after performing experiments for heating purposes with and without internal heat loads. Additionally, Table 3 includes the period, the minimum, maximum and average of the outside air temperatures, and solar irradiance.

Table 4. Total cumulative electrical energy consumption of the heat pumps during heating period of the three studied cubicles, with and without internal heat loads.

\begin{tabular}{|c|c|c|c|c|c|c|c|c|c|}
\hline \multirow{2}{*}{$\begin{array}{c}\text { Type of } \\
\text { experiment }\end{array}$} & \multirow{2}{*}{ Month } & \multirow{2}{*}{$\begin{array}{l}\text { Period } \\
\text { [days] }\end{array}$} & \multirow{2}{*}{$\begin{array}{l}\text { Min./ Max./ Avg. } \\
\text { outside air } \\
\text { temperature }\left[{ }^{\circ} \mathrm{C}\right]\end{array}$} & \multirow{2}{*}{$\begin{array}{c}\text { Average solar } \\
\text { irradiance } \\
{\left[\mathbf{W} \cdot \mathbf{m}^{-2}\right]}\end{array}$} & \multicolumn{3}{|c|}{$\begin{array}{l}\text { Accumulated energy } \\
\text { consumption (kWh) }\end{array}$} & \multicolumn{2}{|c|}{$\begin{array}{c}\text { Average energy } \\
\text { savings (\%) }\end{array}$} \\
\hline & & & & & $\mathrm{GW}^{*}$ & $\mathrm{GF}^{*}$ & $\mathrm{RF}^{*}$ & $\mathrm{GW}^{*}$ & $\mathrm{GF}^{*}$ \\
\hline $\begin{array}{l}\text { With internal heat } \\
\text { loads } 2017 \text { (A) }\end{array}$ & Dec & 13 & $14.9 /-8.2 / 2.8$ & 224.9 & 85.23 & 85.12 & 77.87 & -9.5 & -9.3 \\
\hline $\begin{array}{l}\text { Without internal } \\
\text { heat loads } 2018(\mathrm{~B})\end{array}$ & January & 13 & 20.8/ -3.9/ 8.2 & 270.2 & 71.32 & 71.60 & 67.36 & -5.9 & -6.2 \\
\hline
\end{tabular}

*GW: green wall; GF: green facade; RF: reference.

Although internal heat loads contribute in reducing the energy demand in winter, case A consumed more energy compared with case B (without internal heat loads). Green wall and green facade cubicles consumed about $16 \%$ more energy in case $\mathrm{A}$ than in case $\mathrm{B}$, while in the reference cubicle was increased in $13.5 \%$. This difference in terms of accumulated energy consumption highlights the importance of how weather conditions have a relevant impact on the energy consumption of buildings. Even though case studies A and B were performed in winter for the same period of time, case A registered a lower average temperature of $5.4{ }^{\circ} \mathrm{C}$ and lower mean solar radiation of $45.3 \mathrm{~W} \cdot \mathrm{m}^{-2}$ in comparison to case $\mathrm{B}$. Regarding the implementation of internal loads, the results showed a small increment of the energy consumption in both VGS in comparison to the reference systems, particularly $3.6 \%$ in green wall and

$5113.1 \%$ in green facade.

512 Moreover, the results obtained in the present study showed the opposite trend of those obtained by 513 Djedjig et al. 2017 [22] in a warm and temperate climate (Cfb) at La Rochelle (France) during August 514 and December 2012. The results of that paper showed an important reduction of the heat losses (30\%) 515 through the green wall in winter that resulted in higher energy savings of about 20\% when compared to 516 the reference bare wall. Even though the results obtained by Djedjig et al. show a high potential for heating purposes, they concluded that the results must be taken with caution because of the climate conditions and building characteristics. However, the green wall and the green facade evaluated in this

519 paper in a continental Mediterranean climate (Cfa) showed an increment of the energy consumption of 520 about $6 \%$ (without considering internal loads), and about $9.4 \%$ (considering internal heat loads) when are compared with a bare wall system.

522 
Besides providing important energy savings in summer due to the extra insulation layer of the panels, 524 substrates and plants, the green wall system improves the thermal stability of a building also in winter, 525 but it does not provide a reduction of the energy consumption. The green facade system, which uses deciduous creepers plants (Boston Ivy), takes advantage of the sun and allows solar radiation reaching the building walls during daytime storing part of this energy, nevertheless, the dispersion of branches and the remaining leaves (Figure 1e) still limit the solar gains and also increases the energy consumption. Once Figure 9, Figure 10 and Table 4 are analysed, it can be confirmed that the thermal performance of the three studied cubicles in the analysed winter (Cfa) is basically influenced by outside temperatures, especially at night time, but also for the solar gains throughout the walls. Thus, the lowest energy consumption registered for all the studied cubicles was similar in foggy periods.

\section{Conclusions}

536

As Riley stated in his lessons learnt paper about living walls [37], some of the latest research is less positive than living wall proponents may wish, for that reason new data has to provide more reliable information to the industry to develop new technologies about green walls and green facades. Even though the thermal performance of these systems in summer is widely studied, results for winter are still scarce and controversial. Hence, the experiments presented in this paper encompassed the thermal performance of two different VGS in both, summer and especially in winter. Additionally, this study provides a step forward considering how internal heat loads caused by occupancy influence their final performance.

The main conclusions of the present study are:

- The need of considering internal heat loads generated by occupancy, when passive energy saving systems such as green infrastructures are evaluated for cooling and heating purposes is experimentally confirmed.

- The effectiveness of the green wall and green facade systems decreased $22.5 \%$ and $26.7 \%$, respectively, because of the internal heat loads in summer conditions, but there are still potential energy savings for cooling purposes.

- The cubicle with a green wall system showed the highest thermal stability of the indoor and outdoor surface wall temperatures for both, summer and winter, also when internal heat loads were implemented. Hence, the lower indoor and outdoor temperature variation provided by the green wall compared to the green facade and reference cubicles confirms the higher insulation effect in winter that limits the drop of external wall temperatures at night. This fact becomes 
more relevant in long periods without sun where mean temperatures of green facade and bare wall systems were drastically reduced because of the absence of solar gains.

- It is confirmed that for heating purposes the lower the difference between daily mean outdoor temperatures and indoor desired conditions of a cubicle (comfort conditions at $22^{\circ} \mathrm{C}$ ), the lower the energy consumption of a cubicle. The reference cubicle presented the higher average indoor temperature so that is why less energy was consumed to reach the internal comfort conditions when compared to green wall and green facade systems.

- Furthermore, there are no remarkable differences in terms of daily energy consumption in winter between the green wall and the green facade in the current state. However, a small difference of energy consumption was detected when both greenery systems were compared with the reference. Nevertheless, both VGS are slightly punished in the specific continental Mediterranean climate.

- Green wall system helps in preventing energy losses through the walls when compared with bare walls during night time in winter, but also in cloudy or foggy days with low ambient temperatures. However, it limits the necessary solar gains during daytime.

In agreement with other studies [21, 22], this paper confirms that this type of results cannot be generalized for all climates because of the specific building characteristics and microclimate conditions. Thus, further experimental research is needed to improve the knowledge about the thermal behaviour of green walls in winter and to improve the technology behind the green wall systems and go furthermore than the generally use of these systems for aesthetic purposes. In addition, future studies should explore different heating and cooling strategies, such as shifting the peak energy loads, to take advantage of the time lag detected in the green wall that could improve the energy efficiency of the building and reduce the heating/cooling costs.

\section{Acknowledgements}

The work is partially funded by the Spanish government (ENE2015-64117-C5-1-R (MINECO/FEDER) and ULLE10-4E-1305). GREA is certified agent TECNIO in the category of technology developers from the Government of Catalonia. The authors would like to thank the Catalan Government for the quality accreditation given to their research group (2017 SGR 1537), and the city hall of Puigverd de Lleida. Julià Coma would like to thank Ministerio de Economia y Competitividad de España for Grant Juan de la Cierva, FJCI-2016-30345. 


\section{References}

1. Directive 2012/27/EU of The European Parliament and of the Council of 25 October 2012 on energy efficiency, amending Directives 2009/125/EC and 2010/30/EU and repealing Directives 2004/8/EC and 2006/32/EC, (n.d.).

2. Directive 2010/31/eu of the European Parliament and of the Council of 19 May 2010 on the energy performance of buildings (recast), (n.d.).

3. International Energy Agency (IEA). Technology Roadmap: Energy efficient building envelopes (2013). Available on: http://www.iea.org/publications/freepublications/ (January 2018)., (n.d.).

4. G. Pérez, L. Rincón, A. Vila, J.M. González, L.F. Cabeza, Green vertical systems for buildings as passive systems for energy savings, Appl. Energy. 88 (2011) 4854-4859. doi:10.1016/j.rser.2014.07.055.

5. G. Pérez, J. Coma, I. Martorell, L.F. Cabeza, Vertical Greenery Systems (VGS) for energy saving in buildings: A review, Renew. Sustain. Energy Rev. 39 (2014) 139-165. doi:10.1016/j.rser.2014.07.055.

6. K. Perini, M. Ottelé, A.L.A. Fraaij, E.M. Haas, R. Raiteri, Vertical greening systems and the effect on air flow and temperature on the building envelope, Build. Environ. 46 (2011) 22872294. doi:10.1016/j.buildenv.2011.05.009.

7. A.B. Besir, E. Cuce, Green roofs and facades: A comprehensive review, Renew. Sustain. Energy Rev. 82 (2018) 915-939. doi:10.1016/j.rser.2017.09.106

8. Ottelé, M A Green Building Envelope: A Crucial Contribution to Biophilic Cities. In: F. Pacheco Torgal · J.A. Labrincha M.V. Diamanti · C.-P. Yu H.K. Lee Editors. Biotechnologies and Biomimetics for Civil Engineering. 2015. Springer International Publishing Switzerland https://doi.org/10.1007/978-3-319-09287-4

9. S.B. Sadineni, S. Madala, R.F. Boehm, Passive building energy savings: A review of building envelope components, Renew. Sustain. Energy Rev. 15 (2011) 3617-3631. doi: 10.1016/j.rser.2011.07.014

10. U. Berardi, A.H. GhaffarianHoseini, A. GhaffarianHoseini, State-of-the-art analysis of the environmental benefits of green roofs, Appl. Energy. 115 (2014) 411-428. doi:10.1016/j.apenergy.2013.10.047

11. T. Šuklje, S. Medved, C. Arkar, On detailed thermal response modeling of vertical greenery systems as cooling measure for buildings and cities in summer conditions, Energy. 115 (2016) 1055-1068. doi:10.1016/j.energy.2016.08.095.

12. N.H. Wong, A.Y.K. Tan, P.Y. Tan, N.C. Wong, Energy simulation of vertical greenery systems, Energy Build. 41 (2009) 1401-1408. doi:10.1016/j.enbuild.2009.08.010.

13. I. Pigliautile, M. Chàfer, A.L. Pisello, G. Pérez, L.F. Cabeza, Inter-building assessment of urban 
heat island mitigation strategies: Field tests and numerical modelling in a simplified-geometry experimental set-up, 147 (2020) 1663-1675. doi:10.1016/j.renene.2019.09.082.

14. S. Flores Larsen, C. Filippín, G. Lesino, Modeling double skin green facades with traditional thermal simulation software, Sol. Energy. 121 (2015) 56-67. doi:10.1016/j.solener.2015.08.033.

15. C.Y. Jim, Thermal performance of climber greenwalls: Effects of solar irradiance and orientation, Appl. Energy. 154 (2015) 631-643. doi:10.1016/j.apenergy.2015.05.077

16. U. Mazzali, F. Peron, P. Romagnoni, R.M. Pulselli, S. Bastianoni, Experimental investigation on the energy performance of Living Walls in a temperate climate, Build. Environ. 64 (2013) 57-66. doi:10.1016/j.buildenv.2013.03.005.

17. A. Afshari, A new model of urban cooling demand and heat island—application to vertical greenery systems (VGS), Energy Build. 157 (2017) 204-217. doi:10.1016/j.enbuild.2017.01.008

18. N.H. Wong, A.Y. Kwang Tan, Y. Chen, K. Sekar, P.Y. Tan, D. Chan, K. Chiang, N.C. Wong, Thermal evaluation of vertical greenery systems for building walls, Build. Environ. 45 (2010) 663-672. doi:10.1016/j.buildenv.2009.08.005.

19. Q. Chen, B. Li, X. Liu, An experimental evaluation of the living wall system in hot and humid climate, Energy Build. 61 (2013) 298-307. doi:10.1016/j.enbuild.2013.02.030.

20. E.A. Eumorfopoulou, K.J. Kontoleon, Experimental approach to the contribution of plant-covered walls to the thermal behaviour of building envelopes, Build. Environ. 44 (2009) 1024-1038. doi:10.1016/j.buildenv.2008.07.004.

21. D. Tudiwer, A. Korjenic, The effect of living wall systems on the thermal resistance of the facade, Energy Build. 135 (2017) 10-19. doi:10.1016/j.enbuild.2016.11.023.

22. R. Djedjig, R. Belarbi, E. Bozonnet, Experimental study of green walls impacts on buildings in summer and winter under an oceanic climate, Energy Build. 150 (2017) 403-411. doi:10.1016/j.enbuild.2017.06.032.

23. J. Deng, R. Yao, W. Yu, Q. Zhang, B. Li, Effectiveness of the thermal mass of external walls on residential buildings for part-time part-space heating and cooling using the state-space method, Energy Build. 190 (2019) 155-171. doi:10.1016/J.ENBUILD.2019.02.029.

24. X. Hao, K. Yang, Q. Xing, Y. Lin, H. Tan, Experimental investigation on the thermal performance of a vertical greening system with green roof in wet and cold climates during winter, Energy Build. 183 (2019) 105-117. doi:10.1016/j.enbuild.2018.10.038.

25. K. Perini, F. Bazzocchi, L. Croci, A. Magliocco, E. Cattaneo, The use of vertical greening systems to reduce the energy demand for air conditioning. Field monitoring in Mediterranean climate, Energy Build. 143 (2017) 35-42. doi:10.1016/j.enbuild.2017.03.036.

26. G. Vox, I. Blanco, E. Schettini, Green façades to control wall surface temperature in buildings, Build. Environ. 129 (2018) 154-166. doi:10.1016/j.buildenv.2017.12.002.

27. G. Happle, J.A. Fonseca, A. Schlueter, A review on occupant behavior in urban building energy models, Energy Build. 174 (2018) 276-292. doi:10.1016/j.enbuild.2018.06.030. 
28. S. Naylor, M. Gillott, T. Lau, A review of occupant-centric building control strategies to reduce building energy use, Renew. Sustain. Energy Rev. 96 (2018) 1-10. doi:10.1016/j.rser.2018.07.019.

29. L. Navarro, A. de Gracia, A. Castell, L.F. Cabeza), Thermal behaviour of insulation and phase change materials in buildings with internal heat loads: experimental study. Energy Efficiency, 8(5) (2015) 895-904. doi:10.1007/s12053-015-9330-х

30. J. Romaní, L.F. Cabeza, G. Pérez, A.L. Pisello, A. de Gracia, Experimental testing of cooling internal loads with a radiant wall, Renew. Energy. 116 (2018) 1-8. doi:10.1016/j.renene.2017.09.051

31. J. Coma, G. Pérez, A. de Gracia, S. Burés, M. Urrestarazu, L.F. Cabeza, Vertical greenery systems for energy savings in buildings: A comparative study between green walls and green facades, Build. Environ. 111 (2017) 228-237. doi:10.1016/j.buildenv.2016.11.014.

32. M.C. Peel, B.L. Finlayson, T.A. McMahon, Updated world map of the Köppen-Geiger climate classification, Hydrol. Earth Syst. Sci. 11 (2007) 1633-1644. doi:10.5194/hess-11-1633-2007.

33. J. Payá, J.M. Corberán, A. de Gracia, A. Castell, L.F. Cabeza, Thermal characterization of buildings from the monitoring of the AC system consumption, Energy Build. 116 (2016) 59-68. doi: 10.1016/j.enbuild.2015.12.047

34. American Society of Heating, Refrigerating and Air-Conditioning Engineers, Inc. (1997). Ashrae handbook fundamentals. In R. A. Parsons (Ed.), Nonresidential cooling and heating load calculations (pp. 28.7-28.16). Atlanta: SI Edition.

35. E.S. Document, F.V. Document, S.T.D. Version, Indoor environmental input parameters for design and assessment of energy performance of buildings- addressing indoor air quality , thermal environment, lighting and acoustics Contents, (2006) 1-52.

36. G. Pérez, J. Coma, S. Sol, L.F. Cabeza, Green facade for energy savings in buildings: The influence of leaf area index and facade orientation on the shadow effect, Appl. Energy. 187 (2017) 424-437. doi:10.1016/j.apenergy.2016.11.055

37. B. Riley, The state of the art of living walls: Lessons learned, Build. Environ. 114 (2017) 219232. doi:10.1016/j.buildenv.2016.12.016. 